\title{
The Old Testament Apocrypha in the Slavonic Tradition
}

\author{
Continuity and Diversity \\ Ed. by Lorenzo DiTommaso and Christfried Böttrich, with the assist. of Marina \\ Swoboda
}

[Die alttestamentlichen Apokryphen in der slavischen Tradition. Kontinuität und Vielfalt.]

The Old Testament Apocrypha in the Slavonic Tradition

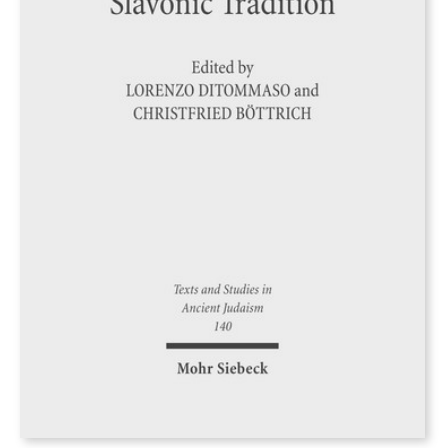

2011. XIV, 486 Seiten. TSAJ 140

ISBN 978-3-16-151473-9

DOI 10.1628/978-3-16-151473-9

eBook PDF 149,00 €

ISBN 978-3-16-149516-8

Leinen $149,00 €$

Veröffentlicht auf Englisch.

Der Sammelband vereint die Arbeiten einer internationalen Gruppe von Spezialisten, die sich mit de Literatur der sogenannten »Alttestamentlichen Apokryphen und Pseudepigraphen« befassen. Dabei geht es ausschließlich um solche Texte, die im slavischen Kulturkreis überliefert worden sind. Schriften wie 2 Henoch oder die Apokalypse Abrahams haben allein in diesem Kontext überlebt; andere wurden bearbeitet oder sind völlig neu konzipiert worden. Die Autoren thematisieren Fragen der Textgeschichte und gehen historischen Bezügen sowie literarischen Strukturen nach. Unter den Beiträgen befinden sich Editionen und Kommentare, Studien zu einzelnen Regionen, Methodenfragen, Textgattungen oder spezifischen Motiven.

Inhaltsübersicht

James H. Charlesworth: The Uniqueness and Importance of the Slavonic Pseudepigrapha - Lorenzo DiTommaso / Christfried Böttrich: The Old Testament Pseudepigrapha in the Slavonic Tradition - F.l. Andersen: The Sun in 2 Enoch: The Book of the Secrets of Enoch - Florentina Badalanova Geller: The Sea of Tiberias between Apocryphal Literature and Oral Tradition Christfried Böttrich: Die »Geschichte Melchisedeks« (HistMelch) im slavischen Kulturkreis - I.M. Gritsevskaya: Some Problems of Textology of Indexes of Prohibited Books - Tomislav Jovanovic: Old Testament Apocrypha in the Serbian Manuscript Tradition - Alexander Kulik: Slavonic Apocrypha and Slavic Linguistics - Basil Lourié: Propitiatorium in the Apocalypse of Abraham - Anissava Miltenova: Slavonic Erotapokriseis: Sources, Transmission, Morphology of the Genre Liudmila Navtanovich: The Slavonic Apocryphon of Zorobabel - Andrei Orlov: The Heirs of the Enochic Lore: »Men of Faith « in 2 Enoch 35:2 and Sefer Hekhalot 48d:10 - Michael Pesenson: The Sibylline Tradition in Medieval and Early Modern Slavic Culture - Nicolae Roddy: Slavonic Apocryphal Traditions in the Romanian Lands: Diffusion and Diffraction - Aurelio de Santos Otero: Die handschriftliche Überlieferung der Apokalypse Abrahams - Cornelia Soldat: The Testaments of the Twe/ve Patriarchs in the Russian Tradition and the Contexts of Their Reception - Marina Swoboda: The Old Testament »Apocrypha« in Early Russian Drama - Evgenij G. Vodolazkin: Zu einer Rohfassung der Polnaja Chronograficeskaja Paleja und zum Verhältnis zwischen den verschiedenen Paleja-Redaktionen

Christfried Böttrich ist Professor für Neues Testament an der Ernst-Moritz-Arndt-Universität Greifswald.

Lorenzo DiTommaso is Associate Professor of Religion at Concordia University, Montréal.

Marina Swoboda is an independent scholar affiliated with McGill University, Montréal.

Jetzt bestellen:

https://mohrsiebeck.com/buch/the-old-testament-apocrypha-in-the-slavonic-tradition-9783161514739?no_cache=1 order@mohrsiebeck.com

Telefon: +49 (0)7071-923-17

Telefax: $+49(0) 7071-51104$ 